\title{
THE OCCURRENCE OF LETHAL FACTORS IN INBRED AND WILD STOCKS OF DROSOPHILA
}

\author{
MARY B. STARK \\ (From the Zoölogical Laboratory, Columbia University) \\ TWO DIAGRAMS
}

Three main points are dealt with in the following account: 1) The relative frequency of sex linked lethal factors in inbred stocks of Drosophila ampelophila in comparison with their occurrence in wild stocks. 2) The occurrence of new lethals and their linkage relations to other sex linked characters. 3) The demonstration that an extraordinary sex ratio was due to the occurrence of two different lethal factors each carried by one of the sex chromosomes of the female that gave the ratio in question.

\section{THE RELATIVE FREQUENCY OF LETHALS IN INBRED AND WILD STOCKS}

A hundred virgin females of a stock of Drosophila which was caught at Falmouth, Mass., in the summer of 1912, were mated individually on November 29, 1912, with males of the same stock. The counts of the offspring from each bottle are shown in table 1.

A hundred virgin females from a stock that had been caught at Falmouth, Mass., in the summer of 1911, were mated individually to males of the same stock early in January, 1913. The results are shown in table 3.

Numbers 13, 36, 38 and 47 of table 3 show a ratio of twice as many females as males while numbers 43,53 and 67 are doubtful.

In order to determine whether the high ratios would reappear in later generations, virgin females from several of these cultures were mated to brothers. The results are shown in table 4 .

Of the four sets of tests two (viz., 36 and 38) give ambiguous results, while numbers 13 and 47 give respectively 5 high to 9 
TABLE 1

\begin{tabular}{|c|c|c|c|c|c|c|c|}
\hline FEMALES & MALES & FEMALE3 & - MALES & FEMALES & MALES & FEMALES & MALES \\
\hline 97 & 98 & $96^{*}$ & 59 & 85 & 81 & 105 & 105 \\
\hline 134 & 147 & 121 & 113 & 93 & 93 & 88 & 79 \\
\hline 77 & 79 & 94 & 99 & 73 & 77 & 58 & 47 \\
\hline 121 & 117 & 116 & 98 & 105 & 108 & 71 & 75 \\
\hline 138 & 144 & 82 & 82 & 34 & 41 & 92 & 82 \\
\hline 132 & 129 & 183 & 166 & 112 & 104 & 47 & 45 \\
\hline 99 & 111 & 117 & 107 & 72 & 74 & 56 & 62 \\
\hline 122 & 142 & 161 & 160 & 85 & 92 & 93 & 80 \\
\hline 127 & 128 & 147 & 140 & 52 & 47 & 89 & 77 \\
\hline 64 & 61 & 62 & 51 & 87 & 92 & 73 & 87 \\
\hline 122 & 152 & 126 & 120 & 88 & 79 & 96 & 92 \\
\hline 95 & 110 & 105 & 112 & 68 & 77 & 69 & 70 \\
\hline 75 & 82 & 50 & 37 & 133 & 112 & 62 & 74 \\
\hline 103 & 120 & 109 & 111 & 72 & 93 & 154 & 142 \\
\hline 112 & 120 & 94 & 97 & 126 & 112 & 203 & 172 \\
\hline 135 & 137 & 112 & 94 & 117 & 123 & 175 & 147 \\
\hline 42 & 47 & 138 & 141 & 102 & 102 & 165 & 154 \\
\hline 166 & 150 & 75 & 74 & 98 & 101 & 120 & 86 \\
\hline 129 & 127 & 100 & 110 & 91 & 80 & $49^{*}$ & 28 \\
\hline 125 & 112 & 65 & 62 & 98 & 101 & 83 & 72 \\
\hline 43 & 50 & 113 & 109 & 128 & 122 & 31 & 21 \\
\hline 157 & 160 & 117 & 105 & 62 & 59 & 42 & 34 \\
\hline 147 & 115 & 109 & 106 & 40 & 42 & 70 & 49 \\
\hline 130 & 111 & 65 & 70 & 48 & 68 & 57 & 52 \\
\hline 67 & 56 & 82 & 88 & 86 & 72 & 80 & 70 \\
\hline
\end{tabular}

* Two matings showed rather high sex ratios, and as this is often indicative of a lethal factor, I mated individually six of the virgin females from each bottle (twelve in all) to males from the same bottles. Since each bottle of the twelve (table 2) gave a $1: 1$ ratio it follows that the somewhat lower values noted in these two bottles was probably merely a chance deviation, or else due to the crowded condition of the bottle which prevented all of the males from hatching out. The males are known to continue hatching for some days after the females have ceased to hatch.

TABLE 2

\begin{tabular}{c|r|r|r}
\hline \multicolumn{2}{c}{$26 \mathbf{F}_{2}$} & \multicolumn{2}{|c}{$94 \mathbf{F}_{2}$} \\
\hline Females & Males & Females & Males \\
\hline 141 & 121 & 87 & 92 \\
128 & 106 & 79 & 74 \\
162 & 150 & 124 & 105 \\
160 & 73 & 177 & 164 \\
130 & 159 & 232 & 212 \\
\end{tabular}


TABLE 3

\begin{tabular}{|c|c|c|c|c|c|c|c|}
\hline No. OF PAIR & FEMALES & MALEES & SEX RATIO & NO. OF PAIR & FEMALES & MALES & SEX RATIO \\
\hline 1 & 290 & 227 & $1.28: 1$ & 51 & 154 & 162 & $0.95: 1$ \\
\hline 2 & 121 & 111 & $1.09: 1$ & 52 & 139 & 108 & $1.28: 1$ \\
\hline 3 & 196 & 200 & $0.98: 1$ & 53 & 56 & 30 & $1.86: 1$ \\
\hline 4 & 176 & 173 & $1.02: 1$ & 54 & 177 & 182 & $0.97: 1$ \\
\hline 5 & 93 & 102 & $0.91: 1$ & 55 & 183 & 145 & $1.26: 1$ \\
\hline 6 & 114 & 134 & $0.85: 1$ & 56 & 75 & 57 & $1.31: 1$ \\
\hline 7 & 132 & 128 & $1.03: 1$ & 57 & 194 & 171 & $1.14: 1$ \\
\hline 8 & 115 & 96 & $1.20: 1$ & 58 & 203 & 195 & $1.04: 1$ \\
\hline 9 & 96 & 92 & $1.04: 1$ & 59 & 158 & 129 & $1.22: 1$ \\
\hline 10 & 95 & 99 & $0.96: 1$ & 60 & 200 & 176 & $1.13: 1$ \\
\hline 11 & 50 & 63 & $0.79: 1$ & 61 & 134 & 114 & $1.17: 1$ \\
\hline 12 & 124 & 142 & $0.87: 1$ & 62 & 45 & 41 & $1.10: 1$ \\
\hline 13 & 232 & 114 & $2.03: 1$ & 63 & 196 & 183 & $1.08: 1$ \\
\hline 14 & 262 & 229 & $1.14: 1$ & 64 & 134 & 106 & $1.26: 1$ \\
\hline 15 & 187 & 188 & $1.00: 1$ & 65 & 136 & 122 & $1.12: 1$ \\
\hline 16 & 212 & 203 & $1.04: 1$ & 66 & 143 & 152 & $0.94: 1$ \\
\hline 17 & 214 & 159 & $1.35: 1$ & 67 & 105 & 63 & $1.66: 1$ \\
\hline 18 & 247 & 220 & $1.12: 1$ & 68 & 147 & 133 & $1.10: 1$ \\
\hline 19 & 169 & 145 & $1.16: 1$ & 69 & 151 & 157 & $0.96: 1$ \\
\hline 20 & 106 & 100 & $1.06: 1$ & 70 & 175 & 159 & $1.10: 1$ \\
\hline 21 & 189 & 149 & $1.27: 1$ & 71 & 121 & 84 & $1.44: 1$ \\
\hline 22 & 155 & 127 & $1.22: 1$ & 72 & 108 & 156 & $0.69: 1$ \\
\hline 23 & 193 & 179 & $1.08: 1$ & 73 & 80 & 71 & $1.12: 1$ \\
\hline 24 & 206 & 169 & $1.22: 1$ & 74 & 106 & 98 & $1.09: 1$ \\
\hline 25 & 230 & 223 & $1.03: 1$ & 75 & 116 & 103 & $1.12: 1$ \\
\hline 26 & 182 & 154 & $1.18: 1$ & 76 & 78 & 59 & $1.32: 1$ \\
\hline 27 & 201 & 168 & $1.20: 1$ & 77 & 60 & 53 & $1.11: 1$ \\
\hline 28 & 178 & 142 & $1.22: 1$ & 78 & 106 & 92 & $1.16: 1$ \\
\hline 29 & 153 & 136 & $1.12: 1$ & 79 & 81 & 69 & $1.18: 1$ \\
\hline 30 & 120 & 79 & $1.52: 1$ & 80 & 148 & 118 & $1.29: 1$ \\
\hline 31 & 166 & 153 & $1.08: 1$ & 81 & 79 & 88 & $0.90: 1$ \\
\hline 32 & 157 & 143 & $1.10: 1$ & 82 & 103 & 107 & $0.96: 1$ \\
\hline 33 & 212 & 155 & $1.37: 1$ & 83 & 126 & 120 & $1.05: 1$ \\
\hline 34 & 225 & 225 & $1.00: 1$ & 84 & 116 & 95 & $1.11: 1$ \\
\hline 35 & 156 & 161 & $1.03: 1$ & 85 & 95 & 94 & $1.01: 1$ \\
\hline 36 & 188 & 81 & $2.32: 1$ & 86 & 114 & 140 & $0.81: 1$ \\
\hline 37 & 172 & 183 & $0.99: 1$ & 87 & 75 & 68 & $1.10: 1$ \\
\hline 38 & 172 & 83 & $2.07: 1$ & 88 & 97 & 98 & $0.99: 1$ \\
\hline 39 & 77 & 92 & $0.83: 1$ & 89 & 119 & 140 & $0.92: 1$ \\
\hline 40 & 125 & 83 & $1.51: 1$ & 90 & 140 & 128 & $1.09: 1$ \\
\hline 41 & 159 & 155 & $1.02: 1$ & 91 & 126 & 124 & $1.06: 1$ \\
\hline 42 & 102 & 95 & $1.07: 1$ & 92 & 133 & 137 & $0.97: 1$ \\
\hline 43 & 74 & 49 & $1.51: 1$ & 93 & 155 & 157 & $0.99: 1$ \\
\hline 44 & 53 & 36 & $1.47: 1$ & 94 & 157 & 148 & $1.08: 1$ \\
\hline 45 & 113 & 77 & $1.49: 1$ & 95 & 118 & 115 & $1.02: 1$ \\
\hline 46 & 69 & 64 & $1.09: 1$ & 96 & 111 & 88 & $1.26: 1$ \\
\hline 47 & 200 & 93 & $2.15: 1$ & 97 & 148 & 138 & $1.01: 1$ \\
\hline 48 & 88 & 89 & $0.98: 1$ & 98 & 105 & 103 & $1.01: 1$ \\
\hline 49 & 56 & 60 & $0.93: 1$ & 99 & 127 & 126 & $1.01: 1$ \\
\hline 50 & 76 & 64 & $1.19: 1$ & 100 & 124 & 120 & $1.01: 1$ \\
\hline
\end{tabular}


TABLE 4

\begin{tabular}{|c|c|c|c|c|c|c|c|}
\hline \multicolumn{4}{|c|}{13} & \multicolumn{4}{|c|}{36} \\
\hline NO. OF PAIR & FEMALES & MALES & SEX RATIO & NO. OF PAIR & FEMALES & MALES & SEX RATIO \\
\hline 1 & 194 & 95 & $2.04: 1$ & 1 & 116 & 128 & $0.91: 1$ \\
\hline 2 & 123 & 50 & $2.46: 1$ & 2 & 114 & 124 & $0.92: 1$ \\
\hline 3 & 123 & 124 & $0.99: 1$ & 3 & 89 & 63 & $1.41: 1$ \\
\hline 4 & 131 & 113 & $1.16: 1$ & 4 & 101 & 107 & $0.94: 1$ \\
\hline 5 & 164 & 61 & $2.70: 1$ & 5 & 100 & 74 & $1.35: 1$ \\
\hline 6 & 108 & 86 & $1.14: 1$ & 6 & 102 & 124 & $0.82: 1$ \\
\hline 7 & 143 & 53 & $2.70: 1$ & 7 & 119 & 96 & $1.24: 1$ \\
\hline 8 & 82 & 104 & $0.79: 1$ & 8 & 92 & 94 & $0.98: 1$ \\
\hline 9 & 193 & 173 & $1.11: 1$ & 9 & 70 & 49 & $1.43: 1$ \\
\hline 10 & 148 & 82 & $1.80: 1$ & 10 & 100 & 80 & $1.25: 1$ \\
\hline 11 & 159 & 143 & $1.11: 1$ & 11 & 194 & 153 & $1.27: 1$ \\
\hline 12 & 87 & 93 & $0.94: 1$ & 12 & 109 & 47 & $2.32: 1$ \\
\hline 13 & 53 & 59 & $0.96: 1$ & 13 & 129 & 105 & $1.23: 1$ \\
\hline 14 & 119 & 173 & $1.50: 1$ & 14 & 124 & 105 & $1.18: 1$ \\
\hline 15 & 165 & 152 & $1.10: 1$ & 15 & 127 & 116 & $1.10: 1$ \\
\hline \multicolumn{4}{|c|}{38} & \multicolumn{4}{|c|}{47} \\
\hline 1 & 112 & 56 & $2.00: 1$ & 1 & 137 & 141 & $0.97: 1$ \\
\hline 2 & 159 & 139 & $1.14: 1$ & 2 & 150 & 157 & $0.96: 1$ \\
\hline 3 & 125 & 78 & $1.61: 1$ & 3 & 140 & 105 & $1.33: 1$ \\
\hline 4 & 67 & 73 & $0.93: 1$ & 4 & 85 & 95 & $0.89: 1$ \\
\hline 5 & 58 & 46 & $1.26: 1$ & 5 & 115 & 107 & $1.08: 1$ \\
\hline 6 & 131 & 90 & $1.45: 1$ & 6 & 127 & 77 & $1.65: 1$ \\
\hline 7 & 90 & 79 & $1.01: 1$ & 7 & 185 & 91 & $2.03: 1$ \\
\hline 8 & 119 & 129 & $0.92: 1$ & 8 & 201 & 81 & $2.45: 1$ \\
\hline 9 & 71 & 78 & $0.91: 1$ & 9 & 119 & 90 & $1.32: 1$ \\
\hline 10 & 153 & 86 & $1.78: 1$ & 10 & 149 & 150 & $0.99: 1$ \\
\hline 11 & 183 & 153 & $1.19: 1$ & 11 & 201 & 92 & $2.20: 1$ \\
\hline 12 & 164 & 117 & $1.40: 1$ & & & & \\
\hline
\end{tabular}

low 1 doubtful and 4 high to 7 low ratios where equal numbers of each kind are expected. Further tests were therefore made. Pairs were mated from 13,$1 ; 13,2 ; 13,5 ; 13,7 ; 36,12 ; 47,7$; 47,$8 ; 47,11$.

The counts from these matings are shown in table 5 .

As expected, the test of 13,1 shows the presence of a lethal since there were 6 high to 6 low ratios.

The test of 13,2 indicates a lethal with 8 high to 11 low ratios. The test of 13,5 indicates a lethal with 6 high to 13 low ratios. 
TABLE 5

13,1

\begin{tabular}{c|c|c|c}
\hline NO. OF PAIR & FEMALES & MALES & SEX RATIO \\
\hline 1 & 186 & 103 & $1.80: 1$ \\
2 & 118 & 122 & $0.97: 1$ \\
3 & 121 & 128 & $1.06: 1$ \\
4 & 116 & 101 & $1.15: 1$ \\
5 & 171 & 81 & $2.11: 1$ \\
6 & 138 & 46 & $3.00: 1$ \\
7 & 120 & 116 & $1.03: 1$ \\
8 & 107 & 52 & $2.06: 1$ \\
9 & 115 & 110 & $1.05: 1$ \\
10 & 104 & 128 & $0.81: 1$ \\
11 & 127 & 108 & $1.86: 1$ \\
12 & 174 & & $1.74: 1$ \\
\hline
\end{tabular}

13,2

\begin{tabular}{c|r|r|r}
\hline NO. OF PAIR & FEMAI.ES & MALEB & SEX RATIO \\
\hline 1 & 159 & 61 & $2.61: 1$ \\
2 & 128 & 146 & $0.88: 1$ \\
3 & 105 & 53 & $2.00: 1$ \\
4 & 212 & 94 & $2.36: 1$ \\
5 & 139 & 101 & $1.37: 1$ \\
6 & 84 & 74 & $1.14: 1$ \\
7 & 135 & 122 & $1.10: 1$ \\
8 & 240 & 100 & $2.40: 1$ \\
9 & 225 & 160 & $1.40: 1$ \\
10 & 77 & 79 & $0.98: 1$ \\
11 & 91 & 69 & $1.38: 1$ \\
12 & 72 & 87 & $0.83: 1$ \\
13 & 109 & 81 & $1.34: 1$ \\
14 & 108 & 84 & $1.17: 1$ \\
15 & 175 & 91 & $1.92: 1$ \\
16 & 222 & 116 & $1.91: 1$ \\
17 & 88 & 40 & $2.22: 1$ \\
18 & 134 & 104 & $1.29: 1$ \\
19 & 145 & 47 & $3.08: 1$ \\
\hline
\end{tabular}

Two high to 9 low ratios appear in 13, 7 , which probably indicates a lethal as the parent also had a high ratio (viz., $2.7: 1$ ).

These four tests of 13 show beyond doubt that a lethal was present, since each of the four families tested gave some high ratios. 
TABLE 5-Continued

13,5

\begin{tabular}{c|r|r|r}
\hline NO. OF PAIR & FEMALES & MALES & SEX RATIO \\
\hline 1 & 116 & 139 & $0.87: 1$ \\
2 & 103 & 100 & $1.03: 1$ \\
3 & 222 & 109 & $2.03: 1$ \\
4 & 140 & 140 & $1.00: 1$ \\
5 & 159 & 58 & $2.75: 1$ \\
6 & 150 & 168 & $0.89: 1$ \\
7 & 205 & 210 & $0.98: 1$ \\
8 & 107 & 44 & $2.43: 1$ \\
9 & 239 & 140 & $1.71: 1$ \\
10 & 164 & 137 & $1.20: 1$ \\
11 & 125 & 117 & $1.07: 1$ \\
12 & 148 & 123 & $1.20: 1$ \\
13 & 172 & 156 & $1.10: 1$ \\
14 & 107 & 115 & $2.14: 1$ \\
15 & 113 & 134 & $0.98: 1$ \\
16 & 100 & 150 & $0.75: 1$ \\
17 & 211 & 133 & $1.41: 1$ \\
18 & 116 & 62 & $0.87: 1$ \\
19 & 155 & & $2.50: 1$ \\
\hline
\end{tabular}

13,7

\begin{tabular}{c|c|c|c}
\hline No. OF PAIR & FEMALES & MALES & BEX RATIO \\
\hline 1 & 267 & 229 & $1.17: 1$ \\
2 & 180 & 161 & $1.11: 1$ \\
3 & 136 & 123 & $1.10: 1$ \\
4 & 208 & 89 & $2.32: 1$ \\
5 & 106 & 106 & $1.00: 1$ \\
6 & 162 & 87 & $2.00: 1$ \\
7 & 139 & 131 & $1.06: 1$ \\
8 & 119 & 140 & $0.85: 1$ \\
9 & 121 & 119 & $1.01: 1$ \\
10 & 109 & 76 & $1.43: 1$ \\
11 & 113 & 83 & $1.36: 1$ \\
\hline
\end{tabular}

Of the 60 females tested, half (30) should have given $2: 1$ ratios, while in fact, only 22 gave such ratios to 38 giving normal ratios. Provisionally, this deviation may be ascribed to chance. 
The following tests were made of the daughters of number 12 of 36 , table 4 :

TABLE 5-Continued

36,12

\begin{tabular}{c|c|c|c}
\hline No. OF PAIR & FEMALES & MALES & SEx Ratio \\
\hline 1 & 121 & 72 & $1.7: 1$ \\
2 & 151 & 56 & $2.8: 1$ \\
3 & 130 & 109 & $1.2: 1$ \\
1 & 159 & 140 & $1.1: 1$ \\
5 & 97 & 115 & $0.8: 1$ \\
6 & 177 & 108 & $1.6: 1$ \\
7 & 135 & 88 & $1.5: 1$ \\
8 & 144 & 55 & $2.6: 1$ \\
\hline
\end{tabular}

In this test there were 5 high to 3 low ratios showing that 36,12 was a lethal bearing female.

The following tests were made of the daughters of number 7 of 47 , table 4 .

TABLE 5-Continued

47,7

\begin{tabular}{c|c|c|c}
\hline NO. OF PAIR & FEMALES & MALES & SEX RATIO \\
\cline { 2 - 3 } 1 & 259 & 121 & $2.1: 1$ \\
2 & 235 & 122 & $1.9: 1$ \\
3 & 188 & 78 & $2.4: 1$ \\
4 & 133 & 152 & $0.9: 1$ \\
5 & 170 & 90 & $1.9: 1$ \\
6 & 185 & 95 & $1.9: 1$ \\
7 & 147 & 148 & $1.0: 1$ \\
8 & 164 & 150 & $1.1: 1$ \\
\hline
\end{tabular}

Here there are 5 high to 3 low ratios indicating a lethal.

In 47,3 the 4 high to 4 low ratios indicate a lethal.

In 47, 1 there are 3 high to 7 low ratios. Of the three sets of tests of 47 of table 5 there were 12 high to 14 low ratios which establishes the presence of a lethal in this line. The general outcome of these tests leaves no doubt that a lethal was present in the original females that were tested.

Since only half of the daughters of a lethal female are heterozygous for lethal and since these females are indistinguishable 
TABLE 5-Continued

47,8

\begin{tabular}{c|r|r|r}
\hline No. OF PAIR & FEMALES & MALES & SEX RATIO \\
\cline { 2 - 3 } $\mathbf{1}$ & 146 & 80 & $1.8: 1$ \\
2 & 93 & 94 & $1.0: 1$ \\
3 & 201 & 162 & $1.2: 1$ \\
4 & 124 & 58 & $2.1: 1$ \\
5 & 147 & 156 & $0.9: 1$ \\
6 & 196 & 69 & $2.8: 1$ \\
7 & 150 & 119 & $1.3: 1$ \\
8 & 158 & 57 & $2.8: 1$ \\
\hline
\end{tabular}

47,11

\begin{tabular}{c|c|c|c}
\hline No. of pair & Frmales & Males & SEx Ratio \\
\cline { 2 - 3 } 1 & 142 & 79 & $1.79: 1$ \\
2 & 168 & 173 & $0.98: 1$ \\
3 & 157 & 171 & $0.92: 1$ \\
4 & 159 & 162 & $0.98: 1$ \\
5 & 167 & 124 & $1.34: 1$ \\
6 & 247 & 124 & $2.00: 1$ \\
7 & 142 & 127 & $1.12: 1$ \\
8 & 190 & 97 & $1.96: 1$ \\
9 & 122 & 146 & $0.90: 1$ \\
10 & 163 & 156 & $1.04: 1$ \\
\hline
\end{tabular}

from their sisters, it is by chance only that one would choose a female with a lethal factor when testing out a stock. On the other hand if a lethal female is mated to a male having a sex

TABLE 6

$13,1,11$

\begin{tabular}{c|c|c|c}
\hline No. OF PAIR & FEMALES & MALES & SEX RATIO \\
\hline 1 & 183 & 156 & $1.11: 1$ \\
2 & 138 & 118 & $1.17: 1$ \\
3 & 155 & 70 & $2.22: 1$ \\
4 & 158 & 139 & $1.12: 1$ \\
5 & 154 & 82 & $1.90: 1$ \\
6 & 142 & 152 & $0.90: 1$ \\
7 & 163 & 152 & $1.01: 1$ \\
\hline
\end{tabular}


TABLE 6-Continued

$13,1,12$

\begin{tabular}{l|r|r|r}
\hline 1 & 114 & 70 & $1.63: 1$ \\
2 & 156 & 136 & $1.12: 1$ \\
3 & 199 & 108 & $1.83: 1$ \\
4 & 154 & 82 & $1.88: 1$ \\
5 & 195 & 102 & $1.92: 1$ \\
6 & 154 & 103 & $1.50: 1$ \\
\hline
\end{tabular}

$13,2,1$

\begin{tabular}{r|r|r|r}
\hline 1 & 123 & 60 & $2.00: 1$ \\
2 & 130 & 52 & $2.50: 1$ \\
3 & 98 & 105 & $0.93: 1$ \\
4 & 82 & 3 & $27.33: 1$ \\
5 & 110 & 95 & $1.15: 1$ \\
6 & 140 & 135 & $1.04: 1$ \\
7 & 170 & 50 & $3.40: 1$ \\
8 & 84 & 62 & $1.35: 1$ \\
9 & 99 & 70 & $1.41: 1$ \\
\hline
\end{tabular}

$13,2,8$

\begin{tabular}{l|r|r|r}
\hline 1 & 83 & 61 & $1.36: 1$ \\
2 & 150 & 62 & $2.42: 1$ \\
3 & 105 & 96 & $1.08: 1$ \\
4 & 156 & 162 & $0.97: 1$ \\
5 & 84 & 39 & $2.16: 1$ \\
6 & 134 & 134 & $1.00: 1$ \\
7 & 120 & 73 & $1.64: 1$ \\
8 & 109 & 64 & $1.54: 1$ \\
9 & 134 & 111 & $1.21: 1$ \\
\hline
\end{tabular}

$13,2,19$

\begin{tabular}{r|r|r|r}
\hline 1 & 164 & 129 & $1.27: 1$ \\
2 & 207 & 214 & $0.92: 1$ \\
3 & 225 & 211 & $1.07: 1$ \\
4 & 232 & 172 & $1.35: 1$ \\
5 & 182 & 185 & $1.00: 1$ \\
6 & 341 & 120 & $2.84: 1$ \\
7 & 283 & 152 & $1.86: 1$ \\
8 & 193 & 93 & $2.07: 1$ \\
9 & 366 & 167 & $2.20: 1$ \\
10 & 251 & 246 & $1.02: 1$ \\
\hline
\end{tabular}


linked factor close to the lethal factor in question a stock may be obtained in which the lethal females may be selected with great probability. For example: If a red eyed female carrying a lethal is mated to a white eyed male half of her daughters will have the factor for red and the factor for lethal in one $\mathrm{X}$ chromosome and the factor for white and the factor that is the normal allelomorph of lethal in the other chromosome. If such a daugh-

TABLE 7

$13,2,8,2$ (four $1: 1$ ratios omitted)

\begin{tabular}{|c|c|c|c|c|c|}
\hline \multirow{2}{*}{ NO. OF PAIR } & \multicolumn{2}{|c|}{ FEMALES } & \multicolumn{2}{|c|}{ MALES } & \multirow{2}{*}{$\begin{array}{l}\text { CROSSING OVER } \\
\text { BETWEEN WHITE } \\
\text { AND LETHALS }\end{array}$} \\
\hline & Red & White & Red & White & \\
\hline 1 & 62 & 73 & 11 & 47 & 19.0 \\
\hline 2 & 87 & 78 & 12 & 48 & 20.0 \\
\hline 3 & 99 & 77 & 23 & 58 & 28.4 \\
\hline 4 & 77 & 67 & 11 & 55 & 16.7 \\
\hline
\end{tabular}

$13,2,19,6$ (five $1: 1$ ratios omitted)

\begin{tabular}{l|r|r|r|r|r}
\hline 1 & $\begin{array}{r}177 \\
2\end{array}$ & $\begin{array}{r}94 \\
110\end{array}$ & $\begin{array}{l}30 \\
19\end{array}$ & $\begin{array}{l}88 \\
81\end{array}$ & $\begin{array}{l}25.4 \\
19.0\end{array}$ \\
\hline \multicolumn{6}{c}{$13,2,19,7$ (three 1} \\
\hline 1 & 83 & 107 & 23 & 69 & 25.0 \\
2 & 112 & 118 & 22 & 93 & 19.1 \\
3 & 98 & 81 & 26 & 68 & 27.7 \\
4 & 162 & 85 & 14 & 79 & 15.1 \\
5 & 89 & 94 & 20 & 71 & 22.0 \\
6 & 98 & 87 & 27 & 72 & 27.3 \\
7 & 82 & 83 & 18 & 65 & 21.7 \\
\hline
\end{tabular}

ter is mated to a white eyed male half of the female offspring will be red eyed and half white eyed. The former getting their red bearing chromosome from their mother will be the lethal bearing females since the red bearing chromosome also carried the lethal factor. By selecting the red eyed females, therefore, in each succeeding generation and breeding them to white eyed males the lethal stock can be maintained.

Virgin females from numbers $13,1,11 ; 13,1,12 ; 13,2,1$; $13,2,8 ; 13,2,19$; of table 5 were mated to white eyed males. The results are shown in table 6 . 
The tests give 19 high to 22 low ratios which is the expectation for lethals, i.e., equality is expected and is approximately realized.

Daughters from $2: 1$ cultures all of which were heterozygous for white and half of which should be heterozygous for lethal also, were again mated to white eyed males with the results in table 7 .

There were 13 high to 13 low ratios shown by these daughters indicating a lethal factor. On the basis of these data the locus of the lethal is at 23.7 .

It is interesting to note that the lethal factor occurred in flies that had been inbred a year and that none appeared in the stock having been inbred only two months. Miss Rawls (Biol. Bull. '13) found her lethal in a stock that had been inbred a year. The lethals described by Quackenbush (Sc. '10) and Morgan (Sc. '12; and Jour. Exp. Zoöl. '14) appeared in stocks that had been inbred for some time. To test whether, in general, lethals are more frequent in inbred stocks I mated 100 pairs from wild stock caught at Falmouth, Mass., and 70 pairs from wild stock caught at Harris, Minn. The results are shown in table 8 .

Tables 1 and 8 show that the counts made of offspring from 270 pairs of fresh wild stocks have no unusual ratios.

\section{THE SECOND LETHAL FACTOR}

On February 10 of 1914, sixty pairs from stock collected in the summer of 1910 were mated. The results are shown in table 9 .

The next to the last pair of the above table seemed to show the presence of a lethal factor. Sixty virgin daughters from this pair were mated to brothers. Nearly one-half of these gave a ratio of twice as many females as males, as shown in table 10 .

Virgin females from numbers $7,8,12,23$ and 59 were mated to white eyed males. About one-third of the counts of the next generation show the presence of a lethal factor (table 11). Some of these lethal females were again mated to white eyed 
TABLE 8 (a)

Falmouth Stock

\begin{tabular}{|c|c|c|c|c|c|c|c|}
\hline FEMALES & MALES & FEMALES & MALES & FEMALES & MALES & FEMALES & MALES \\
\hline 98 & 111 & 129 & 111 & 161 & 132 & 175 & 182 \\
\hline 144 & 132 & 207 & 216 & 175 & 176 & 171 & 174 \\
\hline 74 & 78 & 181 & 154 & 195 & 187 & 191 & 190 \\
\hline 68 & 86 & 182 & 193 & 101 & 118 & 199 & 223 \\
\hline 129 & 120 & 196 & 205 & 102 & 85 & 100 & 88 \\
\hline 120 & 117 & 179 & 187 & 154 & 162 & 99 & 106 \\
\hline 119 & 138 & 191 & 175 & 195 & 190 & 185 & 180 \\
\hline $\mathbf{3 7 8}$ & 174 & 105 & 97 & 191 & 198 & 100 & 84 \\
\hline 176 & 175 & 184 & 181 & 199 & 202 & 174 & 194 \\
\hline 96 & 103 & 173 & 138 & 150 & 150 & 87 & 128 \\
\hline 130 & 109 & 186 & 150 & 166 & 183 & 91 & 90 \\
\hline 156 & 141 & 174 & 169 & 110 & 123 & 98 & 86 \\
\hline 103 & 88 & 170 & 197 & 175 & 177 & 100 & 108 \\
\hline 125 & 152 & 187 & 222 & 176 & 180 & 100 & 93 \\
\hline 105 & 95 & 220 & 182 & 192 & 171 & 146 & 136 \\
\hline 84 & 92 & 186 & 157 & 189 & 172 & 108 & 110 \\
\hline 140 & 188 & 95 & 110 & 175 & 193 & 100 & 92 \\
\hline 128 & 151 & 192 & 200 & 159 & 173 & 85 & 102 \\
\hline 127 & 139 & 174 & 171 & 171 & 159 & 100 & 101 \\
\hline 157 & 193 & 113 & 111 & 177 & 173 & 172 & 160 \\
\hline 120 & 145 & 167 & 119 & 166 & 184 & 183 & 189 \\
\hline 109 & 106 & 123 & 120 & 117 & 81 & 192 & 189 \\
\hline 102 & 100 & 191 & 210 & 159 & 163 & 176 & 180 \\
\hline 148 & 125 & 134 & 129 & 110 & 107 & 164 & 170 \\
\hline 167 & 155 & 106 & 102 & 191 & 199 & 171 & 175 \\
\hline
\end{tabular}

males. It was expected that only a few of the red eyed males would appear in the second generation if red and lethal were closely linked. Results (table 11) show, however, that a great number of red males appear. Such a result indicates that a new lethal had appeared which was located some distance from the factor for white, thus giving a chance for a greater amount of crossing over.

In table 11 it will be noted that the percentage of crossovers is 46. This would place the lethal somewhere beyond the factor for sable and not far from the factor for bar eyes upon the sex chromosome. 
TABLE 8 (b)

Harris Stock

\begin{tabular}{|c|c|c|c|c|c|}
\hline FEMALES & MaLes & FEMALES & MALES & FEMALES & MALES \\
\hline 69 & 166 & 137 & 142 & 83 & 95 \\
\hline 126 & 126 & 117 & 96 & 176 & 167 \\
\hline 158 & 139 & 104 & 104 & 91 & 86 \\
\hline 124 & 121 & 97 & 105 & 175 & 130 \\
\hline 159 & 216 & 115 & 125 & 140 & 139 \\
\hline 163 & 132 & 105 & 98 & 94 & 76 \\
\hline 180 & 170 & 115 & 79 & 138 & 120 \\
\hline 199 & 196 & 84 & 87 & 116 & 115 \\
\hline 154 & 155 & 93 & 81 & 183 & 185 \\
\hline 153 & 153 & 115 & 89 & 163 & 135 \\
\hline 157 & 167 & 93 & 75 & 107 & 78 \\
\hline 165 & 135 & 104 & 105 & 138 & 120 \\
\hline 104 & 117 & 93 & 82 & 164 & 161 \\
\hline 183 & 179 & 110 & 136 & 218 & 229 \\
\hline 136 & 142 & 112 & 110 & 215 & 210 \\
\hline 170 & 156 & 139 & 129 & 211 & 196 \\
\hline 173 & 161 & 144 & 132 & 240 & 244 \\
\hline 151 & 133 & 90 & 87 & 195 & 236 \\
\hline 98 & 98 & 125 & 93 & 162 & 165 \\
\hline 129 & 99 & 88 & 82 & 102 & 98 \\
\hline 122 & 116 & 121 & 119 & 236 & 230 \\
\hline 106 & 95 & 137 & 117 & 144 & 154 \\
\hline 70 & 90 & 134 & 135 & 166 & 167 \\
\hline 96 & 79 & 122 & 96 & 172 & 165 \\
\hline
\end{tabular}

To determine the approximate location of the lethal upon the chromosome virgin females of the fifth generation (table 11) were mated, some to sable males, and some to bar eyed males.

The counts of the second generation of crosses with sable and with bar eyed males are shown in table 12 . The $1: 1$ ratios are omitted.

The data in this table show that the distance of this lethal from bar is 8.3 .

If the locus of the factor for sable is 43 and that for bar is 57 , the data of table 12 show that the locus of the new lethal is $43+23.5$ or 66.5 , since the distance of lethal from the factor for bar is only 8.3. The locus of the lethal must be 'to the right' of both factors since $43+23.5$ or 66.5 is approximately equal 
TABLE 9

\begin{tabular}{|c|c|c|c|c|c|}
\hline FEMALES & MALES & FEMALES & Males & FEMALES & Males \\
\hline 146 & 151 & 164 & 161 & 164 & 169 \\
\hline 157 & 168 & 82 & 125 & 148 & 131 \\
\hline 83 & 79 & 183 & 136 & 266 & 239 \\
\hline 88 & 99 & 197 & 193 & 201 & 216 \\
\hline 95 & 104 & 114 & 93 & 167 & 160 \\
\hline 108 & 103 & 114 & 111 & 133 & 129 \\
\hline 76 & 78 & 96 & 106 & 112 & 140 \\
\hline 140 & 138 & 88 & 86 & 106 & 86 \\
\hline 190 & 213 & 93 & 120 & 116 & 97 \\
\hline 105 & 85 & 114 & 95 & 169 & 173 \\
\hline 100 & 79 & 155 & 230 & 199 & 185 \\
\hline 176 & 152 & 106 & 111 & 181 & 205 \\
\hline 131 & 155 & 98 & 103 & 145 & 154 \\
\hline 102 & 84 & 142 & 119 & 106 & 96 \\
\hline 160 & 133 & 91 & 64 & 110 & 96 \\
\hline 171 & 153 & 138 & 110 & 181 & 197 \\
\hline 250 & 188 & 143 & 135 & 195 & 178 \\
\hline 252 & 216 & 152 & 135 & 142 & 162 \\
\hline 150 & 163 & 180 & 149 & 266 & 108 \\
\hline 139 & 105 & 148 & 134 & 86 & 55 \\
\hline
\end{tabular}

to $57+8.3$ or 65.3 or at 65.6 . The locus indicated by both experiments when the data are weighted proportionately and a correction is made for double crossing over is 66.2.

In the spring of 1914, an interesting lethal turned up in my 1910 stock. Half of the males hatched out as normal males but of the other half, though able to pass through the different stages of metamorphosis, many of them were unable to escape from the pupa case. Those that chanced to do so fell over on one side when trying to walk. I examined all the appendages carefully but noticed no abnormalities. Nevertheless, the legs did not seem strong enough to support the body, nor did they seem to move coördinately and for that reason would so often become entangled with one another that the fly could not get them separated and would die from exhaustion in a day or so. Not any of these males lived longer than two days.

Whether the first lethal of the 1910 and the lethals of the 1911 flies allow any development of the lethal bearing male at all, is still under investigation. 
TABLE 10

\begin{tabular}{|c|c|c|c|c|c|c|c|}
\hline NO. OF PAIR & FEMALES & MALES & SEX RATIO & No. OF PAIR & FEMALES & MALEG & SEX RATIO \\
\hline 1 & 211 & 99 & $2.13: 1$ & 31 & 112 & 49 & $2.28: 1$ \\
\hline 2 & 197 & 87 & $2.26: 1$ & 32 & 56 & 54 & $1.03: 1$ \\
\hline 3 & 161 & 91 & $1.77: 1$ & 33 & 176 & 103 & $1.70: 1$ \\
\hline 4 & 123 & 83 & $1.48: 1$ & 34 & 46 & 51 & $0.90: 1$ \\
\hline 5 & 201 & 100 & $2.00: 1$ & 35 & 143 & 78 & $1.86: 1$ \\
\hline 6 & 64 & 76 & $0.84: 1$ & 36 & 44 & 43 & $1.00: 1$ \\
\hline 7 & 277 & 129 & $2.15: 1$ & 37 & 205 & 128 & $1.60: 1$ \\
\hline 8 & 253 & 125 & $2.02: 1$ & 38 & 49 & 50 & $1.00: 1$ \\
\hline 9 & 63 & 44 & $1.43: 1$ & 39 & $6 \subseteq$ & 27 & $2.19: 1$ \\
\hline 10 & 112 & 67 & $1.67: 1$ & 40 & 26 & 23 & $1.13: 1$ \\
\hline 11 & 96 & 48 & $2.00: 1$ & 41 & 73 & 66 & $1.10: 1$ \\
\hline 12 & 244 & 116 & $2.10: 1$ & 42 & 28 & 14 & $2.00: 1$ \\
\hline 13 & 155 & 92 & $1.68: 1$ & 43 & 160 & 36 & $4.44: 1$ \\
\hline 14 & 69 & 67 & $1.03: 1$ & 44 & 124 & 51 & $2.43: 1$ \\
\hline 15 & 72 & 73 & $1.00: 1$ & 45 & 109 & 43 & $2.30: 1$ \\
\hline 16 & 119 & 69 & $1.72: 1$ & 46 & 45 & 42 & $1.00: 1$ \\
\hline 17 & 168 & 102 & $1.64: 1$ & 47 & 50 & 44 & $1.14: 1$ \\
\hline 18 & 71 & 50 & $1.42: 1$ & 48 & 173 & 90 & $1.92: 1$ \\
\hline 19 & 38 & 12 & $3.00: 1$ & 49 & 115 & 78 & $1.47: 1$ \\
\hline 20 & 90 & 36 & $2.50: 1$ & 50 & 44 & 28 & $1.58: 1$ \\
\hline 21 & 213 & 141 & $1.51: 1$ & 51 & 64 & 30 & $2.00: 1$ \\
\hline 22 & 70 & 60 & $1.16: 1$ & 52 & 58 & 64 & $0.90: 1$ \\
\hline 23 & 208 & 90 & $2.31: 1$ & 53 & 164 & 74 & $2.21: 1$ \\
\hline 24 & 117 & 74 & $1.58: 1$ & 54 & 73 & 70 & $1.00: 1$ \\
\hline 25 & 64 & 61 & 1.05: 1 & 55 & 27 & 29 & $0.93: 1$ \\
\hline 26 & 85 & 60 & $1.41: 1$ & 56 & 103 & 72 & $1.34: 1$ \\
\hline 27 & 69 & 35 & $1.96: 1$ & 57 & 56 & 62 & $0.90: 1$ \\
\hline 28 & 88 & 69 & 1.28: 1 & 58 & 191 & 118 & $1.61: 1$ \\
\hline 29 & 231 & 123 & $1.88:]$ & 59 & 193 & 88 & $2.19: 1$ \\
\hline 30 & 217 & 119 & $1.82: 1$ & 60 & 148 & 85 & $1.74: 1$ \\
\hline
\end{tabular}

Since no lethal has been found in the hundreds of pairs of fresh wild stock examined and since lethals have occurred in many of the inbred stocks, it may appear that inbreeding (with its constraints of confinement and homogeneous feeding) tends to cause the mutation to appear or else the removal of the flies from the competition that takes place under wild conditions makes possible the preservation and continuance of any lethal factors that may appear.

A discussion of these alternatives would involve a fuller knowledge than we have at present of the causes of mutations and the 


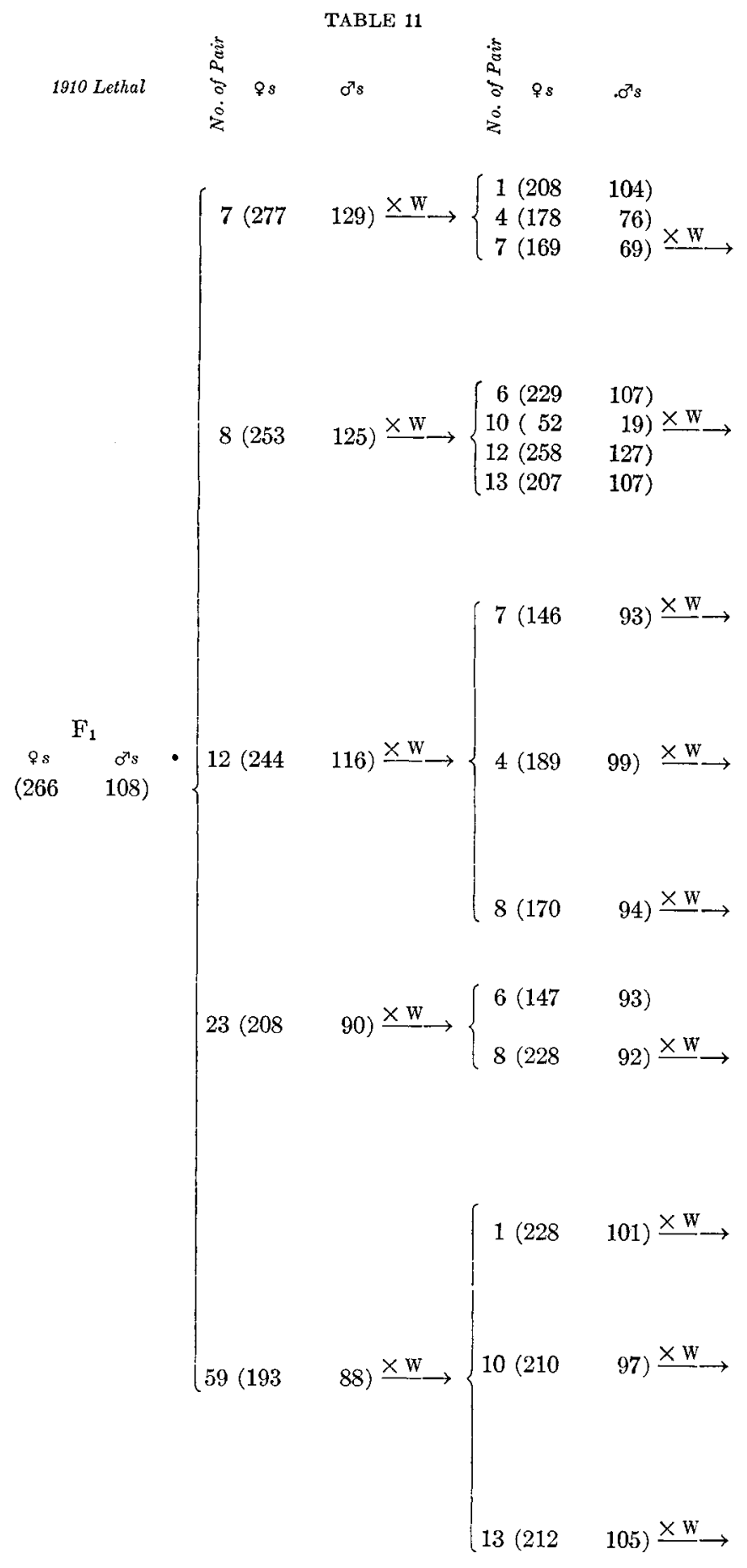

* The $1: 1$ ratios are omitted. 
TABLE 11

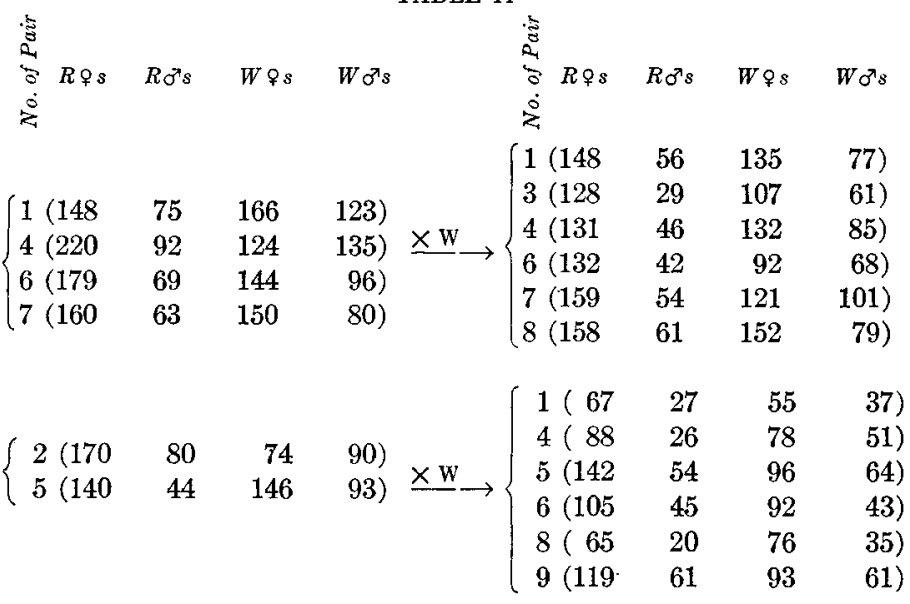

$\left\{\begin{array}{llll}6(175 & 64 & 201 & 95) \\ 7(120 & 44 & 122 & 66) \\ 9(109 & 66 & 118 & 46)\end{array}\right.$

$\left\{\begin{array}{llll}1(133 & 56 & 135 & 68) \\ 3(183 & 76 & 145 & 97) \\ 4(161 & 64 & 162 & 89) \\ 7(160 & 57 & 165 & 84)\end{array} \underset{ }{ }\left(\begin{array}{llllll}3(151 & 52 & 135 & 82) \\ 5(134 & 59 & 117 & 85) \\ 6(132 & 47 & 117 & 73) \\ 7(130 & 53 & 126 & 67) \\ 8(124 & 57 & 112 & 55) \\ 9(128 & 61 & 137 & 68) \\ 10(101 & 42 & 80 & 56)\end{array}\right.\right.$

$1\left(\begin{array}{llll}138 & 68 & 146 & 77\end{array}\right)$

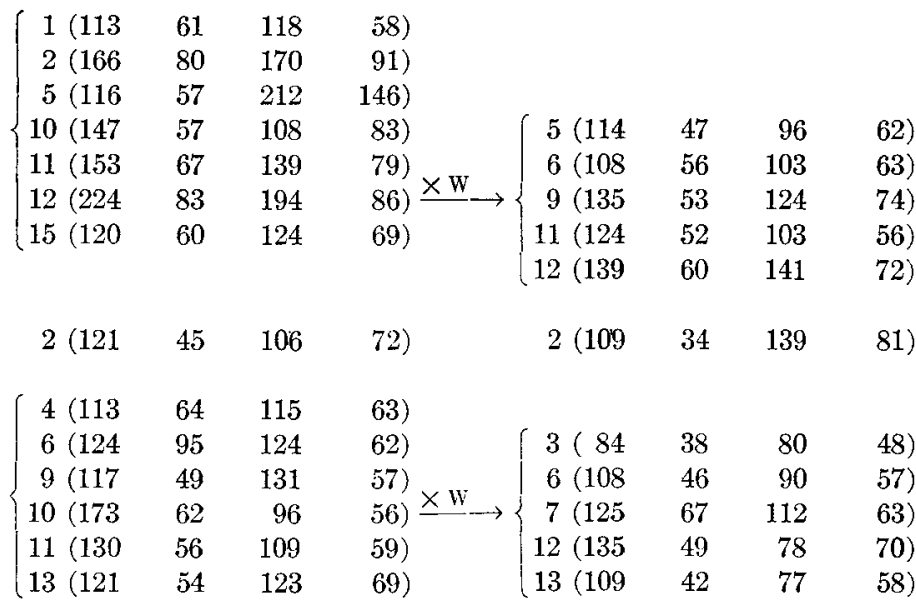

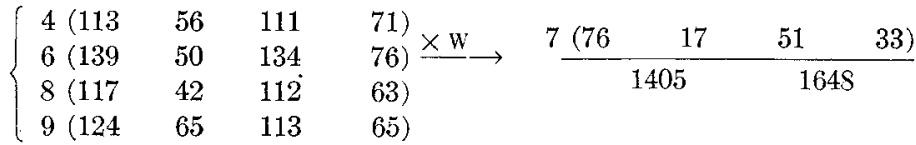

Total no. of of $\mathrm{s}=3053 \quad$ No. of cross overs $=1405$

The ratio of the cross overs to all the $\sigma^{7} \mathrm{~s}=1405 \div 3053=.46$ 
frequency of their appearance. For the present, therefore, the fact of the occurrence of the lethals in the inbred stocks is the one important result of this examination.

\section{THE PRESENCE OF TWO LETHALS}

Number 4 of 13,2 , of table 6 yielded a ratio of $27.33: 1$. It seemed probable in this case that two different lethal factors were present, one in each chromosome. This might seem to prevent all the sons from developing since each son must get one or the other maternal sex chromosome; but the survival of the three males would be possible through the crossing over

TABLE 12 (a)

Heterozygous Bar Female $\times$ Bar Male

\begin{tabular}{|c|c|c|c|c|}
\hline \multirow{2}{*}{ NO. OF PAIIT } & \multirow{2}{*}{$\frac{\text { FEMALES }}{\text { Bar }}$} & \multicolumn{2}{|c|}{ MALES } & \multirow{2}{*}{$\begin{array}{l}\text { CrOBSOVER } \\
\text { PERCENTAGE }\end{array}$} \\
\hline & & Bar & Normal & \\
\hline 1 & 284 & 108 & 5 & 4.4 \\
\hline 2 & 214 & 93 & 13 & 12.3 \\
\hline 3 & 120 & 47 & 3 & 6.0 \\
\hline 4 & 187 & 86 & 12 & 12.2 \\
\hline 5 & 173 & 72 & 4 & 5.3 \\
\hline 6 & 146 & 64 & 8 & 11.1 \\
\hline 7 & 187 & 78 & 8 & 9.4 \\
\hline 8 & 247 & 122 & 5 & 4.2 \\
\hline 9 & 138 & 91 & 4 & 4.2 \\
\hline 10 & 166 & 52 & 4 & 7.1 \\
\hline 11 & 167 & 74 & 11 & 13.0 \\
\hline 12 & 183 & 75 & 12 & 13.0 \\
\hline 13 & 123 & 75 & 10 & 12.0 \\
\hline 14 & 230 & 129 & 10 & 7.1 \\
\hline 15 & 121 & 56 & 3 & 5.0 \\
\hline 16 & 193 & 60 & 7 & 10.0 \\
\hline 17 & 241 & 107 & 10 & 8.0 \\
\hline 18 & 159 & 84 & 2 & 2.3 \\
\hline 19 & 143 & 77 & 9 & 10.0 \\
\hline \multirow[t]{2}{*}{20} & \multirow[t]{2}{*}{139} & 50 & 4 & \multirow[t]{2}{*}{8.0} \\
\hline & & 1590 & 144 & \\
\hline
\end{tabular}

Total number of $o^{x} \mathrm{~s}, 1734$; Crossovers $=144$.

Crossover percentage $=144 \div 1734$ or 8.3 . 
TABLE 12 (b)

Red eyed $\%$ heterozygous for sable and lethal $\times$ sable $\sigma^{7}$

\begin{tabular}{|c|c|c|c|c|c|}
\hline নó. OF PaIR & SABLE & NORMAL & BABLE & NORMAL & $\begin{array}{c}\text { Crossover } \\
\text { PERCENTAGE }\end{array}$ \\
\hline 1 & 45 & 40 & 35 & 6 & 15.0 \\
\hline 2 & 111 & 101 & 80 & 20 & 20.0 \\
\hline 3 & 167 & 112 & 84 & 30 & 26.3 \\
\hline 4 & 110 & 74 & 69 & 21 & 24.6 \\
\hline 5 & 162 & 104 & 95 & 37 & 28.0 \\
\hline 6 & 77 & 59 & 45 & 9 & 17.0 \\
\hline 7 & 149 & 113 & 92 & 22 & 20.0 \\
\hline 8 & 92 & 104 & 58 & 25 & 29.0 \\
\hline 9 & 91 & 105 & 65 & 25 & 27.7 \\
\hline 10 & 85 & 78 & 55 & 16 & 22.5 \\
\hline 11 & 134 & 115 & 78 & 29 & 27.7 \\
\hline 12 & 111 & 113 & 75 & 21 & 22.1 \\
\hline 13 & 138 & 138 & 89 & 33 & 27.0 \\
\hline 14 & 35 & 38 & 35 & 5 & 12.5 \\
\hline 15 & 27 & 52 & 29 & 8 & 21.6 \\
\hline 16 & 121 & 114 & 63 & 21 & 25.3 \\
\hline 17 & 54 & 71. & 48 & 14 & 22.6 \\
\hline 18 & 86 & 91 & 80 & 26 & 24.5 \\
\hline \multirow[t]{2}{*}{19} & \multirow[t]{2}{*}{73} & \multirow[t]{2}{*}{83} & 79 & 19 & \multirow[t]{2}{*}{19.4} \\
\hline & & & 1254 & 387 & \\
\hline
\end{tabular}

The total number of males $=1641$; Crossovers $=387$.

The crossover percentage $=387 \div 1641$ or 23.5 .

Therefore, the distance of lethal from sable is 23.5.

of one of the lethal factors from one chromosome in the other, thus freeing one chromosome from its lethal factor.

TABLE 13

$13,2,1,4$

\begin{tabular}{c|c|c|c|c|c|c}
\hline \multirow{2}{*}{ so. OF PAIR } & \multicolumn{2}{|c|}{ FEMALES } & \multicolumn{2}{c|}{ MATES } & $\begin{array}{c}\text { CROSSING OVER } \\
\text { BETWEEN WHITE } \\
\text { AND LETHAL }\end{array}$ & SEX RATIO \\
\cline { 2 - 5 } & Red & White & Red & White & & \\
\hline 1 & 172 & 174 & 32 & 116 & 21.6 & 2.34 \\
2 & 217 & 228 & 30 & 136 & 18.1 & 2.72 \\
3 & 147 & 174 & 29 & 126 & 18.7 & 2.07 \\
4 & 215 & 216 & 28 & 174 & 13.9 & 2.13 \\
5 & 229 & 194 & 44 & 124 & 26.2 & 2.52 \\
6 & 228 & 209 & 30 & 144 & 17.2 & 2.51 \\
7 & 184 & 201 & 35 & 139 & 20.1 & 2.21 \\
8 & 214 & 212 & 25 & 147 & 14.5 & 2.47 \\
9 & 193 & 155 & 38 & 138 & 21.6 & 1.97 \\
\hline
\end{tabular}


Nine of the daughters were mated individually to white eyed males and gave the results in table 13.

All nine daughters gave a $2: 1$ ratio which is expected if their mother had two lethals.

Ten other daughters (from the very high ratio mother) were mated to their red eyed brothers ${ }^{1}$ and gave the results in table 14.

Six red females of table 13 were tested and gave the following results:

$13,2,1,4,7$

\begin{tabular}{|c|c|c|c|c|c|c|}
\hline \multirow{2}{*}{ No. OF PAIR } & \multicolumn{2}{|c|}{ FEMALES } & \multicolumn{2}{|c|}{ Males } & \multirow{2}{*}{$\begin{array}{c}\text { CROSSING OVER } \\
\text { BETWEEN WHITE } \\
\text { AND LETHAL }\end{array}$} & \multirow{2}{*}{ SEX RATIO } \\
\hline & Red & White & $\operatorname{Red}$ & White & & \\
\hline 1 & 59 & 51 & 4 & 47 & 7.8 & $2.3: 1$ \\
\hline 2 & 88 & 84 & 8 & 59 & 12.0 & $2.6: 1$ \\
\hline 3 & 87 & 66 & 12 & 72 & 15.4 & $1.8: 1$ \\
\hline \multicolumn{7}{|c|}{$13,2,14,8$} \\
\hline 1 & 90 & 80 & 11 & 60 & 15.5 & $2.3: 1$ \\
\hline 2 & 73 & 79 & 10 & 73 & 12.0 & $1.8: 1$ \\
\hline 3 & 75 & 66 & 11 & 63 & 15.1 & $1.9: 1$ \\
\hline
\end{tabular}

Three of the sisters by brother No. 1 failed to produce any progeny when transferred to separate bottles. Each of the other sisters, however, showed the presence of a lethal factor. Thus all 19 daughters of the female gave a $2: 1$ ratio. There can be no question but that the high sex ratio of the mother was due to two lethals. Virgin red eyed daughters of some of these females were then mated to white eyed brothers with results as shown in table 15 .

Since the mothers of the females used in table 15 were all heterozygous for white and for one or the other lethal, they would, when mated to red eyed males, produce two kinds of daughters; one-half heterozygous for a lethal and the other half

\footnotetext{
${ }^{1}$ If the sons that came through were due to crossing over, then the $X$ chromosome that went into each is free from lethals and consequently they must be normal males. The normality of these three males was also tested by mating them to wild females. The sex ratio was normal. The daughters of the three males were tested individually and gave normal ratios.
} 
TABLE 14

Ten sisters by brother No. 1

\begin{tabular}{|c|c|c|c|c|c|}
\hline No. OF PAIR & RED FEMALES & RED MALES & WHITE MALES & SEX RATIO & $\begin{array}{l}\text { CROSSING OVER } \\
\text { BETWEEN WHITE } \\
\text { AND LETHAL }\end{array}$ \\
\hline 1 & 105 & 8 & 41 & $2.14: 1$ & 16.7 \\
\hline 3 & 224 & 23 & 108 & $1.80: 1$ & 17.6 \\
\hline 5 & 64 & 6 & 18 & $2.70: 1$ & 25.0 \\
\hline 6 & 90 & 7 & 36 & $2.09: 1$ & 16.3 \\
\hline 7 & 35 & 2 & 7 & $3.88: 1$ & 22.2 \\
\hline 8 & 38 & 2 & 6 & $4.75: 1$ & 25.0 \\
\hline 9 & 36 & 3 & 12 & $2.40: 1$ & 20.0 \\
\hline Mass. & 428 & 61 & 136 & $2.18: 1$ & 30.9 \\
\hline \multicolumn{6}{|c|}{ Three sisters by brother No. 2} \\
\hline 1 & 128 & 18 & 38 & $2.0: 1$ & 32.1 \\
\hline 2 & 176 & 12 & 78 & $2.0: 1$ & 13.3 \\
\hline 3 & 197 & 11 & 78 & $2.1: 1$ & 12.4 \\
\hline Mass. & 336 & 25 & 109 & $2.5: 1$ & 18.6 \\
\hline
\end{tabular}

heterozygous for white. The females heterozygous for white when mated to white eyed males would produce equal numbers of red eyed and white eyed males and females (table 15) except where the lethal may have crossed over to the factor for white (as was the case in numbers 5 and 1, starred in table 15). ${ }^{2}$ The females heterozygous for lethal when mated to the white eyed males produce the 2:1 ratio, also indicated in table 15 .

Matings were, also, made between the three males and daughters of the sisters of the males with results as follows:

$(13,2,1,4 ;$ Female by $W$ male $) \mathrm{F} ;$ Female by No. 2 male

\begin{tabular}{|c|c|c|c|c|c|}
\hline \multirow{2}{*}{ No. OF PAIR } & \multirow{2}{*}{$\begin{array}{c}\text { FEMALES } \\
\text { Red }\end{array}$} & \multicolumn{2}{|c|}{ MALES } & \multirow{2}{*}{ SEX RATIO } & \multirow{2}{*}{$\begin{array}{l}\text { CROBSING OVER } \\
\text { BETWEEN WHITE } \\
\text { AND LETHAL }\end{array}$} \\
\hline & & Red & White & & \\
\hline Mass & 236 & 6 & 95 & $2.3: 1$ & 5.9 \\
\hline 1 & 172 & 16 & 85 & $1.7: 1$ & 15.8 \\
\hline 2 & 116 & 9 & 43 & $2.2: 1$ & 17.3 \\
\hline 3 & 125 & 7 & 10 & $2.7: 1$ & 14.9 \\
\hline 4 & 141 & 5 & 61 & $2.1: 1$ & 7.6 \\
\hline
\end{tabular}

2 The other class resulting from such crossing over should contain neither the white nor the lethal, and one such female is recorded in table 15. 
TABLE 15

(Sister by No. 1 male), $\mathrm{F}_{2}$

\begin{tabular}{|c|c|c|c|c|c|c|}
\hline \multirow{2}{*}{ NO. OF PAIR } & \multicolumn{2}{|c|}{ FEMALES } & \multicolumn{2}{|c|}{ MALES } & \multirow{2}{*}{ SEX RATIO } & \multirow{2}{*}{$\begin{array}{c}\text { CROSSING OVER } \\
\text { BETWEEN WHTE } \\
\text { AND LETHAL }\end{array}$} \\
\hline & Red & White & Red & White & & \\
\hline 1 & 72 & 80 & 69 & 78 & $1.02: 1$ & \\
\hline 2 & 63 & 48 & 49 & 49 & $1.13: 1$ & \\
\hline 3 & 18 & & 8 & & $2.25: 1$ & \\
\hline 4 & 50 & & 32 & & $1.56: 1$ & \\
\hline $5^{*}$ & 43 & 51 & 27 & 6 & $2.85: 1$ & 18.2 \\
\hline
\end{tabular}

(Sister by No. 1 male) $3 \mathrm{~F}_{2}$

\begin{tabular}{l|r|r|r|r|r|r}
\hline 1 & 145 & & 72 & & $2.00: 1$ \\
2 & 141 & & 75 & & $2.00: 1$ \\
3 & 53 & 67 & 47 & 75 & $1.00: 1$ & \\
4 & 30 & 42 & 32 & 41 & $1.00: 1$ \\
5 & 43 & 34 & 50 & 44 & $0.82: 1$ & \\
6 & 161 & 34 & 67 & 44 & $1.76: 1$ \\
\hline
\end{tabular}

(Sister by No. 2 mxle), $\mathrm{F}_{2}$

\begin{tabular}{|c|c|c|c|c|c|}
\hline $\begin{array}{l}1 \\
2 \\
3 \\
4 \\
5\end{array}$ & $\begin{array}{r}137 \\
103 \\
72 \\
164 \\
101\end{array}$ & 86 & $\begin{array}{r}72 \\
107 \\
81 \\
86 \\
47\end{array}$ & 74 & $\begin{array}{l}1.90: 1 \\
0.90: 1 \\
1.00: 1 \\
2.00: 1 \\
2.10: 1\end{array}$ \\
\hline
\end{tabular}

(Sister by No. 3 male), $3 \mathrm{~F}_{2}$

\begin{tabular}{l|r|r|r|r|r|r}
\hline $1^{*}$ & 101 & 85 & 64 & 14 & $2.40: 1$ & 19.0 \\
2 & 29 & 24 & 24 & 20 & $1.00: 1$ & \\
3 & 168 & & 65 & & $2.60: 1$ & \\
\hline \multicolumn{6}{l}{ (Sister by No. 2 male) Mass $\mathrm{F}_{2}$} \\
\hline 1 & 97 & 69 & 77 & 70 & $1.00: 1$ & \\
2 & 78 & & 24 & & $3.00: 1$ & \\
3 & 153 & & 72 & & $2.00: 1$ & \\
\hline
\end{tabular}

The four daughters show the presence of a lethal.

Summary: The nineteen tested females of $13,2,1,4$ (table 6) gave a $2: 1$ ratio. Other tests showed that the three males behaved like normal males. The explanation of her high ratio $(2: 1)$ is that two lethal factors were present. 
Table 16 gives some of the counts of the descendants of 13 , $2,1,4$ with white eyed males.

TABLE 16

\begin{tabular}{|c|c|c|c|c|}
\hline \multicolumn{2}{|c|}{ FEMALEB } & \multicolumn{2}{|c|}{ MALES } & \multirow{2}{*}{$\begin{array}{l}\text { CROSBING OVER } \\
\text { BETWEEN WHITE } \\
\text { AND LETHAL }\end{array}$} \\
\hline Red & White & Red & White & \\
\hline 162 & 85 & 14 & 79 & 15.0 \\
\hline 228 & 209 & 30 & 144 & 17.2 \\
\hline 100 & 84 & 13 & 68 & 16.0 \\
\hline 91 & 91 & 12 & 68 & 15.0 \\
\hline 127 & 123 & 15 & 85 & 15.0 \\
\hline 122 & 125 & 16 & 108 & 12.8 \\
\hline 127 & 110 & 18 & 117 & 13.3 \\
\hline 115 & 115 & 23 & 119 & 16.2 \\
\hline 95 & 86 & 12 & 57 & 17.4 \\
\hline 142 & 105 & 15 & 88 & 14.5 \\
\hline 137 & 138 & 20 & 118 & 14.4 \\
\hline 43 & 43 & 8 & 39 & 17.0 \\
\hline 87 & 66 & 12 & 72 & 14.3 \\
\hline 90 & 70 & 11 & 60 & 15.5 \\
\hline 108 & 102 & 17 & 79 & 17.7 \\
\hline 72 & 65 & 15 & 53 & 22.0 \\
\hline 76 & 77 & 13 & 48 & 21.3 \\
\hline 120 & 140 & 30 & 120 & 20.0 \\
\hline 119 & 100 & 29 & 90 & 24.3 \\
\hline 130 & 98 & 18 & 69 & 20.7 \\
\hline 149 & 133 & 22 & 95 & 18.8 \\
\hline 193 & 155 & 38 & 138 & 21.6 \\
\hline 229 & 194 & 44 & 124 & 26.2 \\
\hline 172 & 174 & 32 & 116 & 21.6 \\
\hline 193 & 155 & 38 & 138 & 21.6 \\
\hline 184 & 201 & 35 & 139 & 20.1 \\
\hline
\end{tabular}

Numbers 5 and 1 starred of table 15 show a decided decrease in the number of white males. It looked as if the lethal factor had crossed over into the chromosome carrying the factor for white. To examine this, virgin females from number 1 were mated to white eyed miniature males as shown in table 17 .

A lethal factor connected with the factor for white is evidently present since all the white eyed females gave a $2: 1$ ratio.

The red eyed sisters of the white eyed females in table $17 \mathrm{a}$ should bear no lethal if, as the last table indicates, crossing over 
TABLE 17 (a)

White eyed granddaughters of sister and brother by a white eyed miniature male

\begin{tabular}{c|c|c|c}
\hline NO. OF PAIR & WHITE FEMALES & White MALES & SEX RATio \\
\hline 1 & 79 & 44 & $1.8: 1$ \\
2 & 171 & 71 & $2.4: 1$ \\
3 & 176 & 88 & $2.0: 1$ \\
4 & 182 & 90 & $2.0: 1$ \\
5 & 187 & 88 & $2.1: 1$ \\
6 & 176 & 63 & $2.8: 1$ \\
7 & 139 & 48 & $2.9: 1$ \\
8 & 182 & 72 & $2.5: 1$ \\
9 & 170 & 104 & $1.6: 1$ \\
10 & 164 & 68 & $2.4: 1$ \\
\hline
\end{tabular}

had taken place, except when crossing over occurred again in the mother. This was tested (table 17b).

TABLE 17 (b)

Red eyed granddaughters of sister and brother by white eyed miniature male

\begin{tabular}{c|c|c|c|c|c}
\hline \multirow{2}{*}{ No. of PAIR } & \multicolumn{2}{|c|}{ FEMALES } & \multicolumn{2}{|c|}{ MALES } & SEX RATIo \\
\cline { 2 - 4 } & Red & White & Red & White & \\
\hline 1 & 48 & 59 & 20 & 43 & $1.54: 1$ \\
2 & 76 & 78 & 74 & 58 & $1.16: 1$ \\
3 & 82 & 59 & 50 & 50 & $1.41: 1$ \\
4 & 69 & 68 & 66 & 62 & $1.07: 1$ \\
5 & 76 & 52 & 67 & 51 & $1.08: 1$ \\
6 & 65 & 63 & 80 & 61 & $0.90: 1$ \\
7 & 88 & 53 & 29 & 59 & $1.60: 1$ \\
8 & 33 & 34 & 5 & 27 & $2.09: 1$ \\
9 & 42 & 53 & 6 & 35 & $2.32: 1$ \\
10 & 79 & 65 & 1 & 44 & $3.20: 1$ \\
11 & 64 & 99 & 7 & 71 & $2.09: 1$ \\
\hline
\end{tabular}

Four of the red eyed females gave a $2: 1$ ratio indicating that crossing over did occur in the mother.

To determine whether this lethal is the new one or the original one whose locus was shown to be at 23.7 the white eyed females were mated to eosin ${ }^{3}$. to find the locus of the factor in the chromo-

${ }^{3}$ Eosin is an allelomorph of white. A female that has the eosin factor in one $\mathrm{X}$ and the white factor in the other $\mathrm{X}$ can be distinguished from a pure female with eosin in both X's. 
somes. If it is a crossover it should be found to have the same locus as the factor with the red.

The white eyed females mated to eosin males gave white$e^{e o s i n}{ }^{3}$ long winged females (with the factor for lethal): whiteeosin miniature females; white eyed miniature males; and a few white eyed long winged males as crossovers.

The white-eosin long winged females were again mated to eosin miniature males. This mating gave white-eosin long winged females with the lethal factor, eosin miniature females without the lethal factor, eosin long winged females and, white-eosin miniature females, eosin miniature males, white eyed miniature males, eosin long winged males and white long winged males. The single crossovers are the white miniature and the eosin long winged males, while the white long winged males are double crossovers. In table 18 some of the counts are given.

The crossover value of white with the lethal involved is 15.6 and that of the lethal with miniature is 19.9. Therefore the locus of this lethal is at 16.7, that is, 1.1 plus 15.6. The locus of the original lethal was shown to be at 23.7 , so that this lethal with a locus at 16.7 must be the new lethal whose advent led to the production of the high sex ratio. The mother of the high sex ratio carried in one of her $\mathrm{X}$ chromosomes the original lethal at 23.7 and in the other $\mathrm{X}$ chromosome, the one derived from the father, the new lethal at 16.7.

If this female contained two lethals some of her descendants should have one and some the other; and these two kinds should be expected to give slightly different linkage values with white. If, then, the values obtained from all of her descendants be plotted they should give a bimodal curve. Diagram 1 was made from such data except that the diagram does not include the data in table 18.

In diagram 1 there is a strong mode at 15 which corresponds to the new lethal, but the mode which corresponds to the original lethal gives only a weak mode at 22 ; indeed the curve is not obviously bimodal, small number of determinations not being sufficient to distinguish clearly between the two lethals. The 
TABLE 18

\begin{tabular}{|c|c|c|c|c|c|c|c|c|c|c|}
\hline \multirow[b]{2}{*}{$\begin{array}{c}\text { No. } \\
\text { OF PAIR }\end{array}$} & \multicolumn{4}{|c|}{ FEMALES } & \multicolumn{4}{|c|}{ MALES } & \multirow{2}{*}{$\begin{array}{c}\text { LINKAGE } \\
\text { OF WHITE } \\
\text { WITH } \\
\text { LETHAL }\end{array}$} & \multirow{2}{*}{$\begin{array}{c}\text { LINKAGE } \\
\text { OF LETHAL } \\
\text { WITH } \\
\text { MINIATURE }\end{array}$} \\
\hline & $\begin{array}{l}\text { White- } \\
\text { eosin } \\
\text { long }\end{array}$ & $\begin{array}{c}\text { Eosin } \\
\text { minia- } \\
\text { ture }\end{array}$ & $\mid \begin{array}{c}\text { White. } \\
\text { eosin } \\
\text { minia- } \\
\text { ture }\end{array}$ & $\begin{array}{c}\text { Eosin } \\
\text { long }\end{array}$ & $\begin{array}{c}\text { Eosin } \\
\text { minia- } \\
\text { ture }\end{array}$ & $\begin{array}{c}\text { White } \\
\text { minia- } \\
\text { ture }\end{array}$ & $\begin{array}{l}\text { Eosin } \\
\text { long }\end{array}$ & $\begin{array}{c}\text { White } \\
\text { long }\end{array}$ & & \\
\hline & & & & & & & & & $W$ & $M$ \\
\hline 1 & 28 & 32 & 17 & 10 & 27 & 4 & 10 & 0 & 9.8 & 24.4 \\
\hline 2 & 34 & 22 & 24 & 11 & 32 & 7 & 7 & 2 & 18.8 & 18.8 \\
\hline 3 & 35 & 24 & 17 & 18 & 29 & 9 & 6 & 0 & 20.5 & 14.0 \\
\hline 4 & 39 & 35 & 14 & 9 & 29 & 4 & 9 & 0 & 9.5 & 21.4 \\
\hline 5 & 81 & 62 & 69 & 36 & 87 & 15 & 23 & 1 & 12.7 & 19.0 \\
\hline 6 & 66 & 82 & 42 & 25 & 74 & 17 & 20 & 3 & 17.5 & 20.1 \\
\hline 7 & 31 & 11 & 25 & 7 & 25 & 4 & 5 & 0 & $11: 8$ & 14.7 \\
\hline 8 & 34 & 30 & 26 & 17 & 41 & 2 & 9 & 0 & 3.8 & 17.3 \\
\hline 9 & 39 & 42 & 22 & 10 & 42 & 5 & 8 & 0 & 9.0 & 14.4 \\
\hline 10 & 48 & 48 & 51 & 27 & 59 & 9 & 18 & 0 & 10.46 & 20.9 \\
\hline 11 & 28 & 40 & 24 & 15 & 25 & 5 & 10 & 0 & 12.5 & 25.0 \\
\hline 12 & 47 & 44 & 19 & 16 & 48 & 6 & 15 & 0 & 8.7 & 21.7 \\
\hline 13 & 17 & 23 & 14 & 17 & 26 & 6 & 10 & 0 & 14.3 & 24.3 \\
\hline 14 & 44 & 24 & 21 & 11 & 35 & 6 & 10 & 0 & 11.7 & 19.6 \\
\hline 15 & 88 & 62 & 62 & 31 & 63 & 12 & 23 & 0 & 12.2 & 23.4 \\
\hline 16 & 93 & 78 & 37 & 30 & 100 & 10 & 30 & 1 & 8.0 & 22.0 \\
\hline 17 & 113 & 120 & 63 & 80 & 101 & 25 & 37 & 1 & 15.6 & 23.1 \\
\hline 18 & 104 & 105 & 70 & 78 & 83 & 21 & 33 & 3 & 17.1 & 23.5 \\
\hline 19 & 58 & 42 & 39 & 34 & 49 & 15 & 17 & 3 & 21.4 & 23.8 \\
\hline 20 & 87 & 73 & 51 & 46 & 78 & 17 & 18 & 1 & 15.8 & 16.6 \\
\hline 21 & 60 & 60 & 41 & 38 & 44 & 9 & 13 & 1 & 14.9 & 20.9 \\
\hline 22 & 60 & 44 & 38 & 22 & 47 & 16 & 18 & 2 & 21.6 & 24.0 \\
\hline 23 & 48 & 45 & 45 & 22 & 30 & 9 & 13 & 1 & 19.0 & 26.5 \\
\hline 24 & 48 & 35 & 38 & 23 & 58 & 11 & 17 & 1 & 13.8 & 20.7 \\
\hline 25 & 95 & 76 & 54 & 26 & 76 & 26 & 19 & 3 & 23.4 & 17.7 \\
\hline 26 & 58 & 49 & 39 & 29 & 56 & 13 & 14 & 1 & 16.6 & 18.0 \\
\hline 27 & 56 & 35 & 24 & 37 & 64 & 21 & 11 & 3 & 24.2 & 14.1 \\
\hline 28 & 63 & 60 & 49 & 37 & 69 & 20 & 16 & 2 & 20.5 & 17.0 \\
\hline 29 & 54 & 44 & 48 & 33 & 47 & 4 & 11 & 2 & 9.4 & 20.3 \\
\hline 30 & 52 & 39 & 38 & 24 & 55 & 13 & 19 & 1 & 15.9 & 22.6 \\
\hline 31 & 49 & 38 & 37 & 25 & 53 & 5 & 13 & 0 & 7.0 & 18.3 \\
\hline 32 & 53 & 54 & 29 & 16 & 49 & 2 & 9 & 0 & 3.3 & 15.0 \\
\hline 33 & 65 & 45 & 47 & 30 & 71 & 14 & 15 & 1 & 14.8 & 15.8 \\
\hline 34 & 107 & 54 & 67 & 38 & 100 & 21 & 26 & 3 & 16.0 & 19.4 \\
\hline 35 & 101 & 54 & 67 & 29 & 78 & 21 & 28 & 0 & 16.4 & 22.0 \\
\hline 36 & 69 & 48 & 52 & 30 & 63 & 16 & 23 & 2 & 17.3 & 24.0 \\
\hline 37 & 58 & 24 & 66 & 25 & 50 & 8 & 9 & 3 & 15.7 & 17.0 \\
\hline 38 & 57 & 38 & 47 & 25 & 57 & 17 & 17 & 0 & 18.7 & 18.7 \\
\hline 39 & 63 & 45 & 41 & 33 & 54 & 18 & 13 & 1 & 22.1 & 16,2 \\
\hline 40 & 28 & 28 & 19 & 16 & 39 & 8 & 12 & 0 & 13.5 & 20.3 \\
\hline 41 & 60 & 36 & 27 & 26 & 28 & 6 & 4 & 2 & 20.0 & 15.0 \\
\hline 42 & 64 & 34 & 51 & 32 & 71 & 15 & 23 & 1 & 14.5 & 21.9 \\
\hline 43 & 26 & 32 & 45 & 25 & 51 & 8 & 13 & 2 & 13.5 & 20.2 \\
\hline \multirow[t]{2}{*}{44} & 52 & 50 & 46 & 34 & 57 & 24 & 10 & 1 & 27.0 & 12.0 \\
\hline & 2198 & 2174 & 1780 & 1201 & 2421 & 524 & 685 & 48 & 6633 & 8656 \\
\hline
\end{tabular}



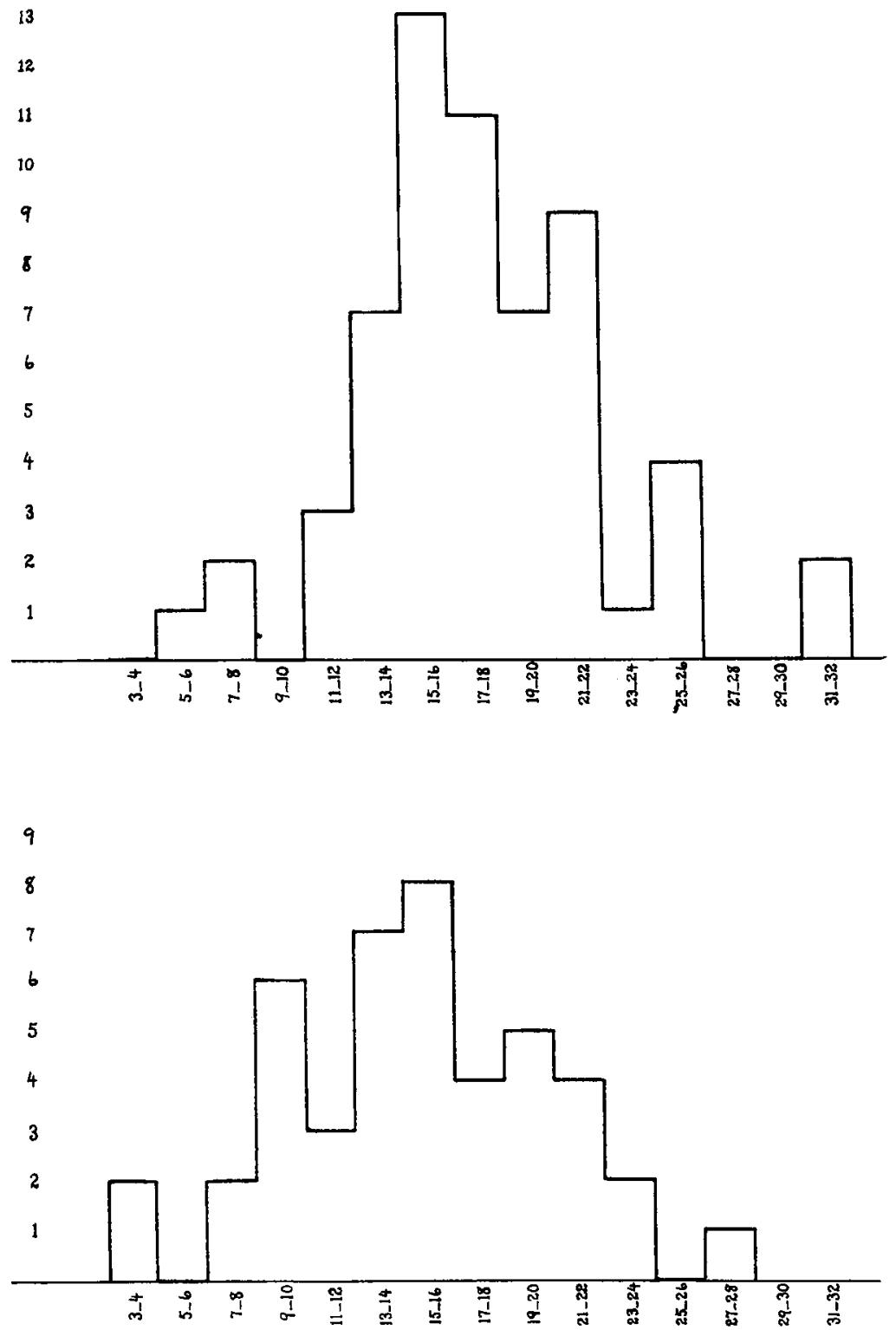
determinations of table 18 are all of the crossover value white new lethal, and are expected to give a unimodal curve with the mode at 15 .

\section{SUMMARY}

Lethal factors were found in inbred stock only. Fresh wild stock gave no unusual sex ratios.

The first lethal $\left(1_{\mathrm{sa}}\right)$ was found in stock caught in 1911 and has its locus at 23.7. One female of this stock gave an extraordinarily high sex ratio; viz., 83 females to 3 males. That this extraordinary sex ratio is due to the presence of two lethal factors, one in each $\mathrm{X}$ chromosome, is shown by the fact that all (not half) the daughters gave a 2 to 1 sox ratio.

The new lethal $\left(l_{\mathrm{sb}}\right)$ that appeared in the female with extraordinary sex ratio crossed over, in one case examined, to the $\mathrm{X}$ chromosome that carried the factor for white. Its locus is at 16.7. Two other lethals were found in the 1910 stock. The first $\left(l_{\mathrm{sc}}\right)$ has its locus at 65.2 . The other $\left(\mathrm{l}_{\mathrm{sd}}\right)$ differs from all other lethals in that the lethal bearing males emerge from the pupa case, and die almost immediately on becoming adult flies. 